\title{
SOIL COMPACTION WITH WHEELS OF MANURE SPREADER AGGREGATES
}

\author{
Aneta MARCZUK ${ }^{1}$, Jan Radek KAMIŃSKI ${ }^{2}$, Gintas VISELGA ${ }^{3 *}$, Vytautas TURLA $^{4}$, \\ Algirdas JASINSKAS ${ }^{5}$, Evgenija UGNENKO ${ }^{6}$ \\ ${ }^{1}$ Institute of Technology and Life Sciences, Branch in Warsaw, Warsaw, Poland \\ ${ }^{2}$ Dept of Biosystems Enginnering, Warsaw University of Life Sciences, Warsaw, Poland \\ ${ }^{3}$ Dept of Mechanics and Materials Engineering, Vilnius Gediminas Technical University, Vilnius, Lithuania \\ ${ }^{4}$ Dept of Mechatronics, Robotics and Digital Manufacturing, Vilnius Gediminas Technical University, \\ Vilnius, Lithuania \\ ${ }^{5}$ Dept of Agricultural Engineering and Safety, Vytautas Magnus University Agriculture Academy, \\ Kaunas, Lithuania \\ ${ }^{6}$ Dept of Researches and Design of Means of Communication, Geodesy and Land Management, \\ Ukrainian State University of Railway Transport, Kharkiv, Ukraine
}

Submitted 12 February 2017; resubmitted 11 March 2018, 26 December 2018; accepted 1 March 2019

\begin{abstract}
The study focused on the definition of the impact of the parameters of the applied manure spreaders (loading capacity, size of tyres, the number of driving wheels) on the numerical values of the basic exploitation indices and on soil compaction as well. Research tests were carried out on farms of different arable land areas. The scope of the study included questionnaire surveys, laboratory and exploitation tests, comparison evaluation of fertilization units, verification of the acquired results, as well as recommendation for practical use. A significant growth in productivity (from 0.38 to $1.15 \mathrm{ha} / \mathrm{h}$ ) was observed together with an increase in the loading capacity of the spreaders, but the following indicators were found to have decreased: surface of soil compaction (from 44 to 15\%), field loading (from 412 to $165 \mathrm{kN} \cdot \mathrm{km}$ ) and grooves volume (from 165 to $67 \mathrm{~m}^{3}$ ). Four-wheel spreader of $20 \mathrm{t}$ loading capacity has been characterized by two times higher values of field loading indices $(357 \mathrm{kN} \cdot \mathrm{km})$, groove loading $(204 \mathrm{kN} / \mathrm{m})$ and groove volume $\left(110 \mathrm{~m}^{3}\right)$ in comparison with a twowheel spreader with a loading capacity of $10 \mathrm{t}$.
\end{abstract}

Keywords: manure spreader, tractor, traction properties, manure fertilization technology, field loading, soil compaction.

\section{Introduction}

Vehicle-imposed soil compaction is one of the serious concerns in agriculture and is an environmental problem that requires a thorough investigation (Taghavifar, Mardani 2014). When choosing the tractor to work with agricultural tools and machinery, the class of tractor is taken into account. The grading of the tractor to the appropriate class includes a number of its parameters, especially the drawbar pull. As the tractors are used for various farm operations and technological treatments in crop and livestock production, they have to meet a very wide range of requirements (DeJong-Hughes et al. 2001).

In recent years, the fleet of machinery and tools, including machinery for manure application, has changed considerably. With increasing frequency farmers are buy- ing high-capacity multipurpose spreaders from 6 to $24 \mathrm{t}$ requiring high-power tractors and universal loaders with equipment for manure loading of capacities ranging from 2.5 to $5.0 \mathrm{t}$ and operating efficiencies ranging from 20 to $50 \mathrm{t} / \mathrm{h}$. The very high ground pressures produced by these vehicles can lead to significant subsoil compaction and a corresponding reduction in crop growth and yield (McBride et al. 2000). With some long-season crops such as corn, farmers must often apply manure to fields either in early spring or late fall, when the soil is relatively wet and more susceptible to compaction and other forms of structural degradation, e.g., plastic deformation or shear failure (Baker 2014; McBride et al. 2000). Estimates suggest that the area of soil degradation due to compaction in Europe

${ }^{*}$ Corresponding author. E-mail: gintas.viselga@vilniustech.lt 
may have exceeded $33 \mathrm{mln}$ ha (Osman 2013). Clay soils often pose an additional challenge with respect to drainage and compaction because they remain in the plastic state for extended periods after drying from wet conditions. Once the upper inch of the soil surface dries out, it becomes a barrier that greatly reduces further evaporation losses. This barrier keeps the soil below in a plastic state, preventing it from being worked or trafficked without causing excessive smearing and compaction damage. For this reason, farmers often fall-till clay soils (Magdoff, Van Es 2021). Adverse effects of soil compaction on crop production have been recognized for many years. It is one of the major problems facing modern agriculture (Hamza, Anderson 2005; Trükmann et al. 2008).

In wetter than normal years, soil compaction can decrease soil aeration and lead to the increased loss of nitrate nitrogen by denitrification, which is the conversion of plant-available nitrate nitrogen into gaseous nitrogen forms that are lost to the atmosphere (Álvaro-Fuentes et al. 2008). This process occurs when soils are in an anaerobic condition and soil pores are mostly filled with water. Reduced soil aeration can affect root growth and function and lead to increased risk of crop disease. All these factors result in increased crop stress and yield loss (McKenzie 2010).

The process of fertilization should not impair the soil (heavy tractors and manure spreaders of high loading capacity excessively compact both soil and subsoil) because such harmful effects cause a reduction in crop yield for many years (Duiker 2005; Jabro et al. 2015a, 2015b). Energy assessment of the mechanical impact of agricultural machinery on soil is presented in the works of Baker (2014) and Alekseev et al. (2012).

Agriculture is also responsible for the release into the atmosphere of about $25 \%$ of the human-made carbon dioxide and $70 \%$ of the nitrous oxide. Tillage, crop-fallow management practices, cropping sequences and the use of nitrogen fertilizers all play significant roles in those emission levels. Scientists are providing guidance to growers on ways to keep soils productive and reduce their climate change footprint by turning to some of agriculture's most tried-and-true practices. They have been studying how no-till systems, crop rotation, ecological (or alternative) cultural practices and nitrogen fertilization can improve soil quality, reduce greenhouse gas emissions, sustain crop yields and reduce the amount of nitrogen polluting the air and water (Sainju, O’Brien 2013).

In Poland around $160 \mathrm{mln} \mathrm{t}$ of manure and organic waste is produced in a year. In this mass, the share of animal production represents about $70 \%$ of the total weight (Wyłuda 2007). An important manure parameter in the process of fertilization is the bulk density, which varies widely from 300 (fresh manure) to $900 \mathrm{~kg} / \mathrm{m}^{3}$ (rotten, compacted), and sometimes even more, depending on factors such as the length of the straw used for bedding, absolute humidity and degree of fermentation. Similar is the case with compost bulk density, which ranges from 600 to $1100 \mathrm{~kg} / \mathrm{m}^{3}$ (Kamiński 2011). These factors affect both the performance of machines and fertilizer costs (Adamowicz 2003).

Modern manure spreaders are required to meet high standards in terms of their functionality, exploitation-economical and safety parameters (BS EN 13080:2002; BS EN 690:1994+A1:2009). Spreaders should be characterized by high-quality work, high loading capacity of the box, minimum tractor power requirement, easy and reliable control of the units - especially the dosing ones - durability and reliability, multipurpose use of the trailer, ease of aggregation with typical agricultural tractors, high efficiency and low cost of use.

Owing to the design, the spreader adapters are divided into a horizontal and a vertical drums systems. Single drum adapters with horizontal drum system are characterized by smaller size and mass, and by simpler design in comparison with other types of adapters. They are also characterized by reduced manure fragmentation, lower lateral uniformity of spreading and lower working widths ranging from 2.5 to $3.5 \mathrm{~m}$. Double drum adapters with horizontal drum system are designed for short or long straw manure and for turf and compost. Spreading width depends on the type of drums and is equal to or a little bigger than the width of the machine.

The construction of double drum adapters with vertically arranged drums allows the spreading of manure along the trailer at adjustable widths up to twice the width of the spreader box. It is designed for hilly areas and for application of small doses of fertilizer (about $10 \mathrm{t} / \mathrm{ha}$ ). Adapters with three vertically arranged spreading drums are rarely used. The drums work as follows: one-drum transmits the fertilizer between two neighbouring drums, which then grind it intensively and enhances the efficiency of the unit, which is very important for the fertilization of meadows.

The quality of work performed by manure spreaders is influenced by many factors. Besides geometrical and kinematic parameters, such as the type and diameter of the drum, the number of drums and their position (horizontal, vertical), the quality is also affected by the properties of manure, operating speed, the used dose, the configuration of the ground, etc. The most important results of the research in this area, mainly from the perspective of comparative assessment, include research at the Institute of Agricultural Technology in Tänikon (Switzerland) (Bernik et al. 2003; Duhovnik et al. 2004).

The study was conducted in terms of precision placement of fertilizer in the field, such as transverse and longitudinal uniformity. The study included the following systems of spreading drums: two horizontal drums, four vertical drums, two large-diameter vertical drums, two horizontal grinding drums and two spreading discs, beater drum with side discharge. In the technology of manure fertilization, the performance of loaders used for loading manure fertilizer onto manure spreaders is particularly important. A loader capacity that is too small results in spreader downtime at the manure heap and limits the performance of the fertilization aggregate. A good solution is 
the ability to fill the spreader in three charging cycles. The loading capacity of the loaders is also important owing to the large loading capacity of spreaders. Popular loaders installed on tractors are increasingly being replaced by selfpropelled loaders characterized by high manoeuvrability, versatility, high loading capacity, and loading height.

A literature review has revealed that much attention has been devoted to economic issues related to the purchase of tractors and modern machinery required in the implemented technologies of crop production. Many research works currently being carried out are related to crop production that is environment friendly. These include poorly explored problems associated with the rational use of fertilization equipment, especially in terms of work organization, energy consumption and the destructive impact of machines on the environment. In the production process the following factors are of great importance: farm area, arable land quality class, soil and climate conditions of the region, crop species, the volume and type of animal production and crop yield height. The obtained yield height is affected by regulatory restrictions on doses of mineral fertilizers and plant protection products, the degree of soil compaction by machines' wheels, especially on wet soils, the degree of contamination of soil and groundwater as a result of the production process, the susceptibility of soil to water and wind erosion. Soil compaction is a global problem owing to mechanized modern agricultural systems and is considered one of the most widespread types of soil degradation affecting agricultural land, soil quality and crop production (Jabro et al. 2014). The compaction of the soil can be estimated by measuring the changes of bulk density, soil water retention, air permeability, or the resistance to penetrometer probes (Berge et al. 2017).

The aim of this study was to determine the effect of the parameters of the manure spreaders used (loading capacity, tyre size, number of wheels) on silty clay loam soil compaction. Absolute humidity of soil at a depth of $0 . .5 \mathrm{~cm}$ amounting to $13 \ldots 15 \%$.

\section{Research methodology}

\subsection{Location, object and subject of study}

Soil compaction, one of the most important processes of soil degradation, is very difficult to detect requiring a close inspection to evaluate the structural changes in the soil and their potential effects on crop growth and development.

The tractors, spreaders and loaders used were evaluated in selected municipalities of Podlaskie district (Poland), where the size of agricultural farms ranged from several to a few hundred hectares. Three experimental farms were chosen according to the following characteristics: suitable area of arable land, applying manure for fertilization purposes, and equipped with tractors, loaders and manure spreaders, enabling the proper selection of machinery for realization of the technological process of manure application. The annual production of manure on the smallest farms was $521.5 \mathrm{t}$, on medium farms $-1665 \mathrm{t}$ and on the largest farms $-6500 \mathrm{t}$. The study was carried out on farms with areas of 28,90 and 290 ha equipped with chargers with capacities of $1.45,1.6$ and $4.0 \mathrm{t}$ and manure spreaders of both old and new types with capacities of 5, 10 and $20 \mathrm{t}$. Fertilized fields were located at the following distances from the compost heap: farm $\mathrm{A}-0.3 \mathrm{~km}$, farm B $-3.0 \mathrm{~km}$, and farm C $-29 \mathrm{~km}$.

Important soil conservation means in field crop production, reputed tillage of soil with adequate moisture regime at optimum terms (Chen et al. 2005). Farms had medium-heavy soil, and their basic crops were cereals, potatoes, and maize; the livestock included mainly pigs, dairy cows and fat stock. Absolute humidity of the soil in relation to the fresh weight during fertilization treatment on each field was as follows: farm A - $12 \%$, farm B $-12 \%$, farm $C-15 \%$. Fertilized fields include the following types of ground: silty clay loam soil (United States Department of Agriculture (USDA) classification: 20\% sand, 20\% clay and $60 \%$ silt), stubble after winter cereals, after harrowing with disc harrows, characterized by absolute humidity of soil at a depth of $0 . .5 \mathrm{~cm}$ amounting to $13 \ldots 15 \%$. We used gravimetric soil water content fixing method.

The standard instrument to measure penetration resistance is cone penetrometer. For the determination of soil penetration resistance we used an electronic RIMIK digital self-writing penetrometer CP20 (England) with a standard $12.5 \mathrm{~mm}$ diameter and cone angle of 30 tip to measure the cone index. According to American Society of Agricultural and Biological Engineers (ASAE) Standard - ASAE S313.3:1999(R2013), the penetration into the soil was performed with $0.02 \mathrm{~m} / \mathrm{s}$ constant velocity. Soil resistance to this tip pressing is recorded in the memory of this apparatus every $15 \mathrm{~mm}$ from the surface to the set depth.

The objects of consideration were the variants of fertilization aggregates - tractor-loader and tractor-spreader which differ by engine power, loading capacity of spreader and lifting capacity of loader. Selection of tractors cooperating with machines was made in terms of drawbar pull demand, aggregate stability, the required working speed and operating efficiency.

The subjects of the study were the relationships occurring in the technological operations of loading and spreading manure between the technical parameters of fertilizing machinery and their operational indicators, including soil compaction by the wheels of manure fertilization aggregates.

\subsection{General assumptions}

The fertilization technologies under study were calculated and evaluated under the following general assumptions:

"'» dose of manure: $30 \mathrm{t} / \mathrm{ha}$;

"» average distance of field from the compost pile, depending on farm size: from 0.3 to $30 \mathrm{~km}$;

"» loading of manure onto the mechanical spreader directly from the compost pile using loaders with loading capacities ranging: from 1.6 to 4 t; 
"») transport's speed of spreader with loading: from 15 to $40 \mathrm{~km} / \mathrm{h}$;

"» transport's speed of spreader without loading: from 20 to $40 \mathrm{~km} / \mathrm{h}$;

"» working speed of the aggregate: from 8 to $15 \mathrm{~km} / \mathrm{h}$;

"» class of manure spreaders' loading capacities: 5, 10 and $20 \mathrm{t}$.

\subsection{Choice of machinery for technology used}

To run the field tests, farms were selected with an appropriate set of machines (tractors, loaders and spreaders) to ensure fertilization with manure at a fixed agrotechnic season. For purposes of comparison the analysis and calculations were based on the selected (according to own experience) sets of machines, after studying both the literature and the observed trends in design and technology for the mechanization of organic fertilization.

The technical characteristics of the tractors used in the operational tests are summarized in Table 1. In the operational research, two tractor loaders and Manitou selfpropelled loader with equipment for loading manure and compost were used. The brief technical characteristics of the loaders are included in Table 2. In the technological operation of manure spreading, spreaders with adapters suited to the application of manure and compost were used, which also ensured good quality of work (uneven lateral spread of less than 30\%) and appropriate cooperation with loaders and tractors. The abbreviated technical characteristics of manure spreaders are provided in Table 3 . The fertilizing aggregates applied in the farms are shown in Figure 1.

\subsection{Compacted area of the field}

The field surface compaction caused by the wheels of tractors and machinery has been defined as a percentage share of the area of traces (ruts) made by the wheels of tractor and spreader within their working time in relation to the total area of the field. It is equal to the ratio of the width of ruts and the working width of spreader multiplied by 100\% (Żebrowska, Marczuk 2014):

$$
k_{s}=\frac{S_{w}}{S_{m}} \cdot 100,
$$

where: $k_{s}$ the percentage share of the compacted field area [\%]; $S_{w}$ the width of wheel tracks left and right [m]; $S_{m}$ the machinery working width $[\mathrm{m}]$.

Quantity, defined as $[\mathrm{N} \cdot \mathrm{m}]$, has been assumed as the indicator of the level of field loading by the working passages of the tractor-spreader aggregate. It is the product of the sum of the weight of the tractor, spreader and half of the loading and the distance travelled by the aggregate with working width $B$ in relation to 1 ha.

The calculation of this indicator $k_{o b}$ was carried out according to the following formula:

$$
k_{o b}=\left(G_{t}+G_{s}+0.5 \cdot G_{f}\right) \cdot L_{B},
$$

where: $k_{o b}$ is the indicator of the level of field loading by the working passages of the tractor-spreader aggregate $[\mathrm{N} \cdot \mathrm{m}]$; $G_{t}$ is the tractor weight $[\mathrm{N}] ; G_{s}$ the spreader weight $[\mathrm{N}] ; G_{f}$ the weight of the fertilizer [N]; $L_{B}$ the distance travelled by an aggregate over 1 ha $[\mathrm{m}]$.

The degree of soil compaction within the tracks of the driving wheels of the machinery refers to the average axial stresses caused by the mass of the tractor, spreader and mass of manure occurring during the work of the aggregate. The total loading is the sum of the total axial thrusts of the tractor and spreader with half the weight of the manure (capacity), and it amounts to (Żebrowska, Marczuk 2014):

$$
k_{u g}=N_{t f a}+N_{t r a}+N_{s f a}+N_{s r a}
$$

where: $k_{u g}$ is summary total axle thrust of a fertilizer aggregate [N]; $N_{t f a}$ the tractor front axle thrust [N]; $N_{t r a}$ the tractor rear axle thrust $[\mathrm{N}] ; N_{s f a}$ the spreader front axle thrust [N]; $N_{\text {sra }}$ the spreader rear axle thrust [N].

However, the total loading divided by the width of the left and right wheel tracks of the aggregate gives us the unit pressure exerted by the aggregate per metre of compacted surface and was determined by the following formula (Żebrowska, Marczuk 2014):

$$
N_{j}=\frac{k_{u g}}{S_{w}},
$$

where: $N_{j}$ is unit pressure $[\mathrm{N} / \mathrm{m}]$.

An important indicator $V_{k}$ is the volume of ruts formed on the surface of 1 ha. This volume is equal to the cross section of the ruts multiplied by the distance travelled by the fertilizing aggregate on the surface of 1 ha and is given by the following formula (Żebrowska, Marczuk 2014):

$$
V_{k}=S_{w} \cdot H_{k} \cdot L_{B}
$$

where: $V_{k}$ is the ruts volume on the surface of 1 ha $\left[\mathrm{m}^{3}\right]$; $H_{k}$ the average value of depth of a rut [m].

Rolling resistance of a spreader depends on the spreader weight, weight of the load and the ground. The ground may be paved road, unsurfaced road, meadow, stubble field after ploughing and cultivating or after harrowing. The ground is characterized, with sufficient simplification, by the rolling resistance coefficient $f$ of taking a value from 0.1 to 0.2 . For fertilized fields of stubble ploughed with a disc harrow to a depth of $10 \ldots 15 \mathrm{~cm}$, with a relatively low soil moisture content $(10 \ldots 15 \%)$, the rolling resistance coefficient $f$ assumes the value 0.15 .

We used the following general formula for calculating the rolling resistance of the spreader:

$$
R=f \cdot\left(G_{s}+G_{f}\right) \text {, }
$$

where: $R$ - rolling resistance of the spreader $[\mathrm{N}] ; f$ - rolling resistance coefficient.

By substituting into this formula the numerical values of the weights of particular spreaders and loads, we obtained the values of rolling resistance of the individual machines. Taking into account rolling resistance, the proper 
Table 1. Shortened technical characteristics of tractors

\begin{tabular}{|c|c|c|c|c|c|c|c|}
\hline \multirow{2}{*}{ Tractor make and type } & \multirow{2}{*}{$\begin{array}{c}\text { Rated power } \\
{[\mathrm{kN}]}\end{array}$} & \multicolumn{2}{|c|}{ Tyre size } & \multirow{2}{*}{$\begin{array}{l}\text { Total mass } \\
{[\mathrm{kg}]}\end{array}$} & \multirow{2}{*}{$\begin{array}{c}\text { Axle base } \\
{[\mathrm{m}]}\end{array}$} & \multicolumn{2}{|c|}{ Wheel track [m] } \\
\hline & & front & rear & & & front & rear \\
\hline \multicolumn{8}{|c|}{ Farm $A$} \\
\hline Renault 106.54 & 100 & $380 / 85 \mathrm{R} 28$ & $420 / 85 \mathrm{R} 38$ & 4905 & 2.75 & 1.90 & 1.80 \\
\hline Renault 95.14 & 85 & $360 / 70 \mathrm{R} 28$ & 480/70R34 & 4740 & 2.50 & 1.80 & 1.65 \\
\hline \multicolumn{8}{|c|}{ Farm B } \\
\hline Renault 103.54 & 95 & 420/70R28 & $16.9 \mathrm{R} 38$ & 4800 & 2.50 & 1.80 & 1.70 \\
\hline Valtra N 121 & 137 & $480 / 65 \mathrm{R} 28$ & $600 / 65 \mathrm{R} 38$ & 4950 & 2.56 & 1.80 & 1.80 \\
\hline \multicolumn{8}{|c|}{ Farm C } \\
\hline JCB 8250 Fastrac & 260 & $540 / 65 R 38$ & 710/70R38 & 10135 & 3.12 & 1.95 & 1.85 \\
\hline
\end{tabular}

Table 2. Abbreviated technical characteristics of loaders

\begin{tabular}{|l|c|c|c|c|}
\hline \multicolumn{1}{|c|}{ Loader make and type } & $\begin{array}{c}\text { Total weight } \\
{[\mathrm{kg}]}\end{array}$ & $\begin{array}{c}\text { Type of bucket } \\
(\mathrm{grab})\end{array}$ & $\begin{array}{c}\text { Loading capacity } \\
{[\mathrm{kg}]}\end{array}$ & $\begin{array}{c}\text { Lifting height } \\
{[\mathrm{m}]}\end{array}$ \\
\hline \multicolumn{7}{|c|}{ Farm A } \\
\hline Mailleux MX 6000 & $550 \quad$ Farm B & 1600 & 3.5 \\
\hline \multicolumn{7}{|c|}{ Farm C $C$} & fork-rake & 1450 & 3.2 \\
\hline Agram 26 & $505 \quad 7220 \quad$ fork-rake & 4000 & 7.0 \\
\hline
\end{tabular}

Table 3. Abbreviated characteristics of manure spreaders

\begin{tabular}{|l|c|c|c|c|c|}
\hline Spreader make and type & $\begin{array}{c}\text { Loading } \\
\text { capacity }[\mathrm{kg}]\end{array}$ & Tyre size & $\begin{array}{c}\text { Machinery } \\
\text { weight }[\mathrm{kg}]\end{array}$ & $\begin{array}{c}\text { Size length/ width/ } \\
\text { height }[\mathrm{m}]\end{array}$ & $\begin{array}{c}\text { Tyre of spreading } \\
\text { adapter }\end{array}$ \\
\hline \multicolumn{7}{|c|}{ Farm A } \\
\hline Duchesne 575 & 5000 & 12.5 R20 & 2000 & $3.7 / 2.0 / 0.8$ & 1 horizontal drum \\
\hline \multicolumn{7}{|c|}{ Farm B } & $5.0 / 1.5 / 1.8$ & 2 vertical drums \\
\hline MIRO SH1220S & 10000 & 18.4 R34 & 3540 & \\
\hline \multicolumn{7}{|c|}{ Farm C } & vertical drums \\
\hline
\end{tabular}


Figure 1. Fertilizing aggregates applied in farms A, B and C

class of a tractor was selected. The tractor class approximately corresponds to the drawbar pull down achieved in certain field conditions. The selection of the tractor was made in reference to a catalogue of agricultural machinery, as well as the Polish Standards (PN-82/R-36107:1982; PN-82/R-36108:1982) for tractor hitching and three-point suspension systems.

\section{Course, results of tests and discussion}

To determine the degree of soil compaction within the aggregate driving wheel traces we used two indicators. The first defines the loading of the 1 ha area by the fertilizing aggregate, whereas the second one defines the driving wheels pressure measured by the loading exerted per unit width of the driving wheels traces. 
Working widths of manure spreaders were based on tests carried out in the laboratory and fields of the Mazovian Research Centre in Kłudzienko (Poland). An example of the measuring procedure is provided in Figure 2.

The tests of a manure spreader with two-drum adapter used for the application of fermented manure of weight volume 960 and $600 \mathrm{~kg} / \mathrm{m}^{3}$ have shown that for the transversal unevenness of the spreading below $30 \%$ its working width amounts to $8 \mathrm{~m}$.
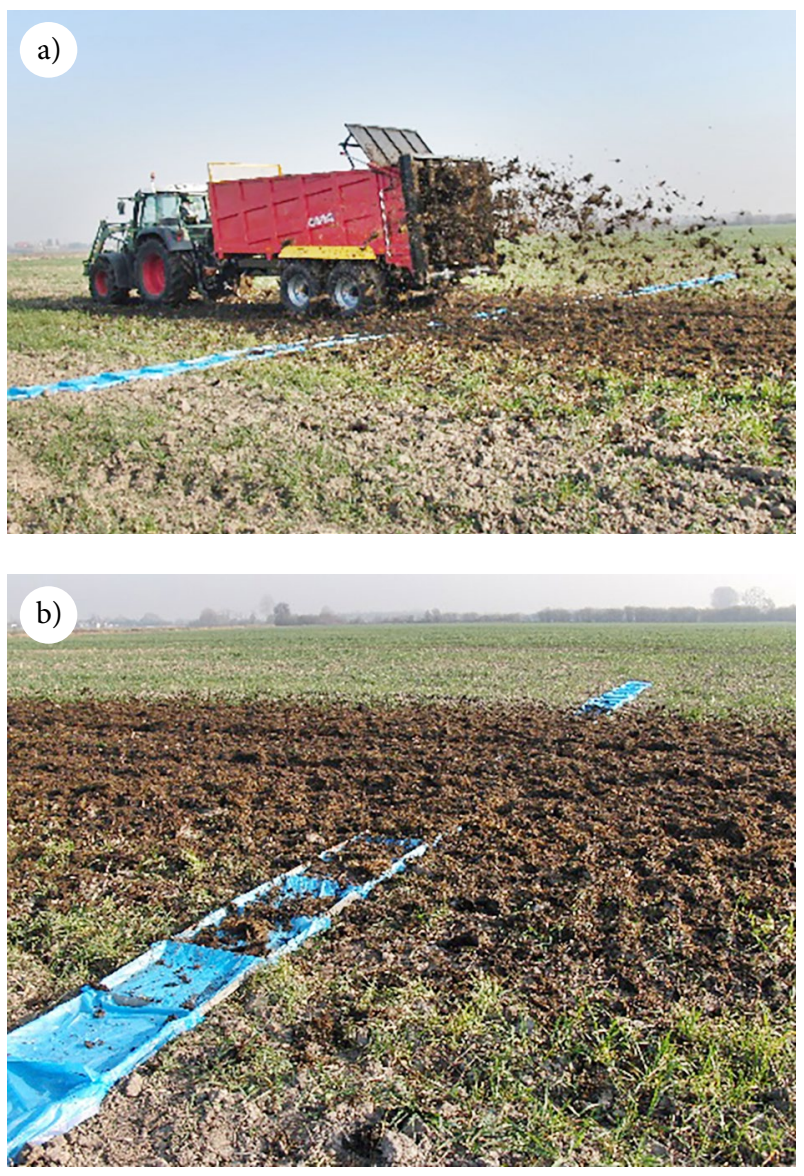

Figure 2. Manure spreader made by the Wielton company with 2 vertical drum spreading adapter when testing the transversal unevenness of manure spreading: a - movement of machinery over the laterally situated boxes for manure; $b$ - distribution of manure in the boxes and on the field
The spreaders were equipped with the following adapters: the smallest one with horizontal one-drum adapter, and the other two with two-drum vertical adapters. Operating capacities of manure spreaders are included in Table 4.

Operational capacities of 5 and $10 \mathrm{t}$ spreaders were similar $(0.48$ and $0.52 \mathrm{ha} / \mathrm{h})$, but the operational capacity of the $20 \mathrm{t}$ spreader, at a distance of $29 \mathrm{~km}$ between pile and field, amounted to $0.38 \mathrm{ha} / \mathrm{h}$ only (mark C), and at a distance of $6 \mathrm{~km}$ (mark $\mathrm{C}^{\star}$ ) it was significantly higher and amounted to $1.15 \mathrm{ha} / \mathrm{h}$. Operating performances of the loaders were proportional to their capacities and were as follows: 30 t/h (charger Mailleux MX 6000), 60 t/h (charger Agram 26) and 120 t/h (Charger Manitou MLT 741120). The loaders' capacities per 1 ha were, respectively: $1.0 \mathrm{ha} / \mathrm{h}$ (loader Mailleux MX 6000), $1.59 \mathrm{ha} / \mathrm{h}$ (loader Agram 26) and 3.4 ha/h (loader Manitou MLT 741-120).

The results of the calculations of the compacted field surface during manure spreading operations are presented in Table 5.

The data in Table 5 show that the greatest share of the compacted field - 39.0...43.6\% - occurred with the aggregate comprising $5 \mathrm{t}$ spreader (farm A), the medium one $(16.3 \ldots 17.8 \%)$ with the aggregate equipped with $20 \mathrm{t}$ spreader (farm C) and the smallest (11.8..15.0\%) with the aggregate equipped with $10 \mathrm{t}$ spreader (farm B). Similar values were obtained for the analysed additional sets of machines of particular groups, the differences being within a small percentage.

The values of the loading index in the 1 ha area of the working crossing of the tractor-spreader aggregate tested on the farm are shown in Table 6. Table 6 also includes the values of the above index for the tractor and manure spreader sample aggregates with similar technical param-

Table 4. Operating capacities of manure spreaders

\begin{tabular}{|l|c|c|c|}
\hline $\begin{array}{c}\text { Farm } \\
\text { symbol }\end{array}$ & $\begin{array}{c}\text { Distance } \\
\text { between pile } \\
\text { and field [km] }\end{array}$ & $\begin{array}{c}\text { Fertilized area with } \\
\text { dose of } 30 \text { t/ha n } \\
\text { operational cycle } \\
\text { [ha] }\end{array}$ & $\begin{array}{c}\text { Operational } \\
\text { capacity } \\
\text { [ha/h] }\end{array}$ \\
\hline A & 0.30 & 0.17 & 0.48 \\
\hline B & 6.00 & 0.33 & 0.52 \\
\hline C & 29.00 & 0.66 & 0.38 \\
\hline $\mathrm{C}^{\star}$ & 6.00 & 0.66 & 1.15 \\
\hline
\end{tabular}

Table 5. Percentage share of the compacted field surface during manure spreading operation

\begin{tabular}{|l|l|c|c|c|}
\hline $\begin{array}{c}\text { Farm } \\
\text { symbol }\end{array}$ & \multicolumn{1}{|c|}{$\begin{array}{c}\text { Fertilizing aggregate: } \\
\text { tractor and spreader }\end{array}$} & $\begin{array}{c}\text { Width of wheel traces } \\
\text { left and right [m] }\end{array}$ & $\begin{array}{c}\text { Machine working } \\
\text { width [m] }\end{array}$ & $\begin{array}{c}\text { Percentage share of } \\
\text { compacted field surface [\%] }\end{array}$ \\
\hline A & Renault 95.14 + Duchesne 575 & 1.0 & 2.2 & 43.6 \\
\hline A1 & New Holland T5.95 + Ursus N-218 & 0.9 & 2.2 & 39.0 \\
\hline A2 & Kubota M9540 + Ursus N-228 & 1.0 & 2.2 & 43.6 \\
\hline B & Valtra N121 + MIRO SH120S & 1.2 & 8.0 & 15.0 \\
\hline B1 & Case Maxxum 125 + Rolland RT115 & 0.9 & 8.0 & 11.8 \\
\hline B2 & John Deere 6534 + JOSKIN Siroko S5010/11V & 1.2 & 8.0 & 15.0 \\
\hline C & JCB Fastrac 8250 + Rolland Rollmax 6325 & 1.4 & 8.0 & 17.8 \\
\hline C1 & Case IH Puma 215 + Rolland RT165 & 1.3 & 8.0 & 16.3 \\
\hline C2 & Case IH Puma200 + Rolland RT195 & 1.3 & 8.0 & 16.3 \\
\hline
\end{tabular}


eters as the three groups of manure spreaders $(5,10$ and 20 t capacity).

For comparison, Table 6 contains the calculated values of the percentage share of the field surface compacted by the working passages of some example fertilizing aggregates available in the Polish market of agricultural machinery.

As shown in Table 6, in the tested farms the loading of 1 ha of the field surface by the working passages of fertilizing aggregates was as follows: $412 \mathrm{kN} \cdot \mathrm{km}$ (farm A), $357 \mathrm{kN} \cdot \mathrm{km}$ (farm C) and $165 \mathrm{kN} \cdot \mathrm{km}$ (farm B). However, in the analysed groups of machines the maximum deviations between each set were as follows: 30\% (group of $20 \mathrm{t}$ spreaders), $23 \%$ (group of $5 \mathrm{t}$ spreaders) and 10\% (group of $10 \mathrm{t}$ spreaders).

The values of the index of driving wheel pressure are presented in Table 7.
As shown in Table 7, the unit values of pressure differ significantly, and they increase with the increasing loading capacity of the manure spreader. The lowest value, amounting to $96.9 \mathrm{kN} / \mathrm{m}$, is characteristic of the aggregate with manure spreader of $5 \mathrm{t}$ loading capacity; the average value, $111.9 \mathrm{kN} / \mathrm{m}$, is characteristic of the aggregate with spreader of $10 \mathrm{t}$ capacity, and the highest, $204.0 \mathrm{kN} / \mathrm{m}$, for aggregate with spreader of $20 \mathrm{t}$ loading capacity.

Rolling resistance of machines depends on many factors, and as it is calculated in accordance with the adopted methodology, it is used for comparative purposes only and for choice of tractors with the required pulling force suitable for spreaders. Since the rolling resistance of the spreader depends on the degree of filling of the fertilizer box, it has been classified into full, partial (1/2) and empty fertilizer box. The results of the calculations for the three analysed spreaders are displayed in Table 8.

Table 6. Values of the field loading index by working passages of the tractor-spreader aggregate

\begin{tabular}{|c|c|c|c|c|}
\hline $\begin{array}{l}\text { Fertilizing aggregate: } \\
\text { tractor and spreader }\end{array}$ & $\begin{array}{l}\text { Weight of tractor, } \\
\text { spreader and half } \\
\text { of loading }[\mathrm{kN}]\end{array}$ & $\begin{array}{l}\text { Working } \\
\text { width }[\mathrm{m}]\end{array}$ & $\begin{array}{l}\text { Route travelled } \\
\text { by aggregate } \\
\text { on } 1 \mathrm{ha}[\mathrm{km}]\end{array}$ & $\begin{array}{c}\text { Loading of } 1 \text { ha } \\
\text { of field } \\
\text { surface }[\mathrm{kN} \cdot \mathrm{km}]\end{array}$ \\
\hline \multicolumn{5}{|c|}{ Farm $A$} \\
\hline Renault $95.14+$ Duchesne 575 & 90.64 & 2.20 & 4.55 & 411.96 \\
\hline New Holland T5.95 + Ursus N-218 & 90.74 & 2.20 & 4.55 & 412.41 \\
\hline Kubota M9540 + Ursus N-228 & 69.80 & 2.20 & 4.55 & 317.24 \\
\hline \multicolumn{5}{|c|}{ Farm B } \\
\hline Valtra N121 + MIRO SH120S & 132.34 & 8.00 & 1.25 & 165.42 \\
\hline Case Maxxum 125 + Rolland RT115 & 126.25 & 8.00 & 1.25 & 157.81 \\
\hline John Deere 6534 + JOSKIN Siroko S5010/11V & 140.92 & 8.00 & 1.25 & 176.15 \\
\hline \multicolumn{5}{|c|}{ Farm $C$} \\
\hline JCB Fastrac 8250 + Rolland Rollmax 6325 & 285.81 & 8.00 & 1.25 & 357.26 \\
\hline Case IH Puma 215 + Rolland RT165 & 192.86 & 8.00 & 1.25 & 241.08 \\
\hline Case IH Puma200 + Rolland RT195 & 215.82 & 8.00 & 1.25 & 269.78 \\
\hline
\end{tabular}

Table 7. Values of the unit pressure in trace of aggregate driving wheels

\begin{tabular}{|c|c|c|c|c|c|c|}
\hline \multirow{2}{*}{ Farm symbol } & \multicolumn{4}{|c|}{ Weight $[\mathrm{kN}]$} & \multirow{2}{*}{$\begin{array}{c}\text { Traces width } \\
{[\mathrm{m}]}\end{array}$} & \multirow{2}{*}{ Unit pressure $[\mathrm{kN} / \mathrm{m}$} \\
\hline & tractor & spreader & $1 / 2$ of loading & total & & \\
\hline A & 47.40 & 19.62 & 25.00 & 92.02 & 0.96 & 96.90 \\
\hline B & 49.50 & 34.73 & 50.00 & 134.23 & 1.20 & 111.90 \\
\hline $\mathrm{C}$ & 101.35 & 88.29 & 100.00 & 289.64 & 1.42 & 204.00 \\
\hline
\end{tabular}

Table 8. Rolling resistance of manure spreaders

\begin{tabular}{|c|c|c|c|c|}
\hline Spreader weight $[\mathrm{kN}]$ & Loading weight $[\mathrm{kN}]$ & Total weight $[\mathrm{kN}]$ & Filling of the fertilizer box & Rolling resistance $[\mathrm{kN}]$ \\
\hline \multicolumn{5}{|c|}{ Farm $\boldsymbol{A}$} \\
\hline 19.62 & 49.05 & 68.67 & full box & $6.69 \ldots 13.74$ \\
\hline 19.62 & 24.53 & 44.15 & $1 / 2$ box & $4.41 \ldots 8.83$ \\
\hline 19.62 & 0 & 19.62 & empty box & $1.96 \ldots 3.92$ \\
\hline 34.73 & 98.10 & 132.83 & full box & $13.28 \ldots 26.57$ \\
\hline 34.73 & 49.05 & 83.78 & $1 / 2$ box & $8.38 \ldots 16.76$ \\
\hline 34.73 & 0 & 34.73 & empty box & $3.47 \ldots 6.95$ \\
\hline \multicolumn{7}{|c|}{ Farm C } \\
\hline 88.29 & 196.20 & 284.49 & full box \\
\hline 88.29 & 98.10 & 186.39 & $1 / 2$ box & $28.45 \ldots 56.90$ \\
\hline 88.29 & 0 & 88.29 & empty box & $8.83 \ldots 17.66$ \\
\hline
\end{tabular}


On the basis of the values of manure spreader rolling resistance contained in Table 8 , we can conclude that the spreader with a capacity of $5 \mathrm{t}$ requires a tractor of $9 \mathrm{kN}$ class (in favourable soil and climatic conditions) or $14 \mathrm{kN}$ (in heavy soil and climatic conditions); a spreader with a capacity of $10 \mathrm{t}$ requires the tractor class 14 and $30 \mathrm{kN}$; but the $20 \mathrm{t}$ loading capacity spreader requires a tractor of the 30 or $60 \mathrm{kN}$ class.

Track depth depends on many factors, one of which is the degree of filling of the loading box. We therefore measured the depth and width of the tractor front wheels tracks, the tractor rear wheels tracks, as well as the front and the rear wheels of the manure spreader; the results are presented in Table 9.

On the basis of the measurements of the width and depth of the tracks and the results obtained, it can be stated that the depth of the tracks made by the tractor front wheels increases as the spreader box is discharged, and the degree to which the box is emptied does not significantly affect the depth of the tracks made by the rear axle of the tractor. It is due to the effect of the load transferred from the front to the rear axle.

After total passing of the aggregate, the track depth decreases as the fertilizer box is emptying. Assuming the maximum values of track depth, width and length, their volume per 1 ha has been calculated. The following values for each farm have been achieved: for farm A $-155.89 \mathrm{~m}^{3}$, for farm B $-60.90 \mathrm{~m}^{3}$ and for farm $\mathrm{C}-110.94 \mathrm{~m}^{3}$.

The highest value of the index in farm A results from the small working width of manure spreader.

Figure 3 shows the compacted field surface, field loading and loading in ruts, and ruts volume over one hectare in the case of the three machine aggregates in farms A, B and C.
The largest area of compacted field was observed for set A (43.63\%), but significantly lower values were observed for sets B (15.00\%) and C (17.75\%). The above was mainly due to the large differences in working widths of manure spreaders. Field loading by the weights of tractors and manure spreaders and by the mass of manure was the highest $(411.96 \mathrm{kN} \cdot \mathrm{km} / \mathrm{ha})$ for a spreader of $5 \mathrm{t}$ capacity, lower $(357.26 \mathrm{kN} \cdot \mathrm{km} / \mathrm{ha})$ for a $20 \mathrm{t}$ spreader and the lowest for a $10 \mathrm{t}$ spreader $(165.42 \mathrm{kN} \cdot \mathrm{km} / \mathrm{ha})$. Rut loading, i.e., loading per unit width of a track, was the lowest for the $5 \mathrm{t}$ spreader and about $10 \%$ higher for the $10 \mathrm{t}$ spreader, but for the $20 \mathrm{t}$ spreader it was twice as high. Soil cone index is a widely used soil mechanical property to assess soil strength in tillage research. A common soil mechanical property used to assess soil strength in tillage studies is soil penetration resistance. The soil penetration resistance measured by a cone penetrometer is also named as soil cone index. Cone index has been used as an important indicator for soil compaction, the performance of tractors and aggregates. Experimental data showed that at the depth of $10 \ldots 290 \mathrm{~mm}$ the highest cone index $(1450 \ldots 2500 \mathrm{kPa})$ was observed in the $\mathrm{C}$ farm, but significantly lower values were observed in $\mathrm{A}(1300 \ldots 1800 \mathrm{kPa})$ and $\mathrm{B}(1020 . .1640 \mathrm{kPa})$ farms. Cone indices had a general tendency to increase with soil depth. In summary, from the point of view of fields compaction, the best performance is that by the manure spreader of $10 \mathrm{t}$ capacity. This proves the wellselected wheel size relative to the capacity of the manure spreader.

Figure 3 shows that the best values of these indicators are for set $B$ with a manure spreader of $10 \mathrm{t}$ capacity.

When fields are being fertilized, some areas are passed several times. During the experiment, we used a $3730 \mathrm{~kg}$ mass

Table 9. Results of measurements of tracks' width and depth

\begin{tabular}{|c|c|c|c|c|c|c|}
\hline \multirow{3}{*}{$\begin{array}{l}\text { Wheels } \\
\text { tracks }\end{array}$} & \multicolumn{6}{|c|}{ Level of spreader box filling } \\
\hline & \multicolumn{2}{|c|}{ Full box } & \multicolumn{2}{|c|}{$1 / 2$ box } & \multicolumn{2}{|c|}{ Empty box } \\
\hline & $\begin{array}{c}\text { left side } \\
\text { depth / width } \\
{[\mathrm{mm}]}\end{array}$ & $\begin{array}{c}\text { right side } \\
\text { depth/width } \\
{[\mathrm{mm}]}\end{array}$ & $\begin{array}{c}\text { left side } \\
\text { depth/width } \\
{[\mathrm{mm}]}\end{array}$ & $\begin{array}{c}\text { right side } \\
\text { depth/width } \\
{[\mathrm{mm}]}\end{array}$ & $\begin{array}{c}\text { left side } \\
\text { depth/width } \\
{[\mathrm{mm}]}\end{array}$ & $\begin{array}{c}\text { right side } \\
\text { depth/width } \\
{[\mathrm{mm}]}\end{array}$ \\
\hline \multicolumn{7}{|c|}{ farm $A$} \\
\hline 1 tractor axle & $31 / 375$ & $34.5 / 380$ & $32.5 / 380$ & $33.5 / 380$ & $35.5 / 380$ & $36.5 / 380$ \\
\hline 2 tractor axle & $34 / 490$ & $35.5 / 490$ & $32.5 / 490$ & $33 / 490$ & $32.5 / 480$ & $34.5 / 480$ \\
\hline Spreader axle & $36 / 490$ & $37 / 490$ & $35 / 490$ & $35 / 490$ & $34 / 480$ & $35 / 480$ \\
\hline \multicolumn{7}{|c|}{ Farm B } \\
\hline 1 tractor axle & $17 / 445$ & $15.5 / 450$ & $21 / 450$ & $20.5 / 450$ & $23 / 450$ & $24.5 / 450$ \\
\hline 2 tractor axle & $24.5 / 580$ & $31.5 / 580$ & $33.5 / 580$ & $37 / 575$ & $28.5 / 580$ & $30.5 / 580$ \\
\hline Spreader axle & $46.5 / 580$ & $44.5 / 580$ & $42 / 580$ & $42 / 580$ & $33.5 / 450$ & $32 / 580$ \\
\hline \multicolumn{7}{|c|}{ Farm $C$} \\
\hline 1 tractor axle & $35 / 570$ & $37 / 570$ & $42 / 570$ & $43 / 570$ & $53 / 570$ & $51 / 570$ \\
\hline 2 tractor axle & $56 / 710$ & $57 / 710$ & $55 / 710$ & $56 / 710$ & $50 / 710$ & $51 / 710$ \\
\hline $\begin{array}{l}\text { Spreader front } \\
\text { wheels }\end{array}$ & $61 / 710$ & $64 / 710$ & $62 / 710$ & $63 / 710$ & $55 / 710$ & $54 / 710$ \\
\hline $\begin{array}{l}\text { Spreader rear } \\
\text { wheels }\end{array}$ & $62 / 710$ & $61 / 710$ & $59 / 710$ & $59 / 710$ & $54 / 710$ & $52 / 710$ \\
\hline
\end{tabular}



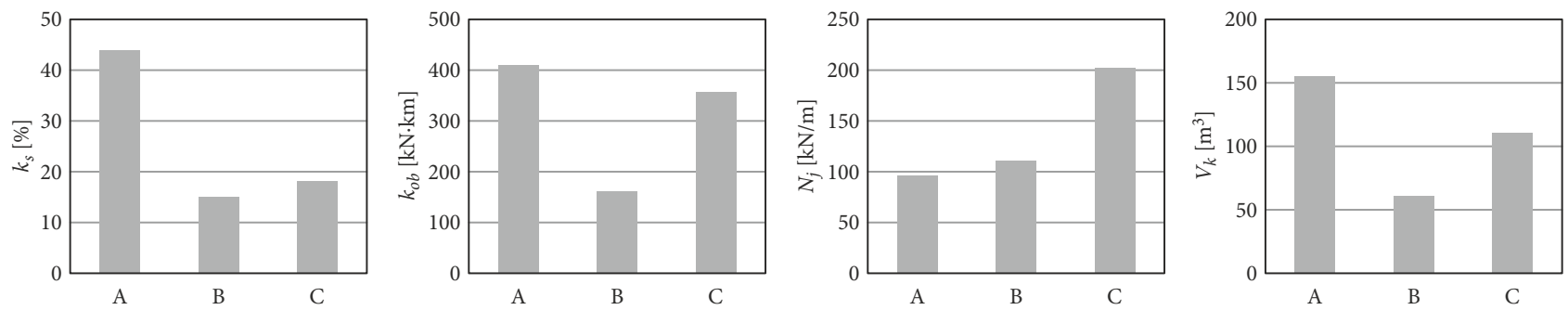

Figure 3. Compacted surface $k_{s}$, field loading $k_{o b}$, loading in a rut $N_{j}$ and ruts volume $V_{k}$ for three machine aggregates in farms $\mathrm{A}, \mathrm{B}$ and $\mathrm{C}$

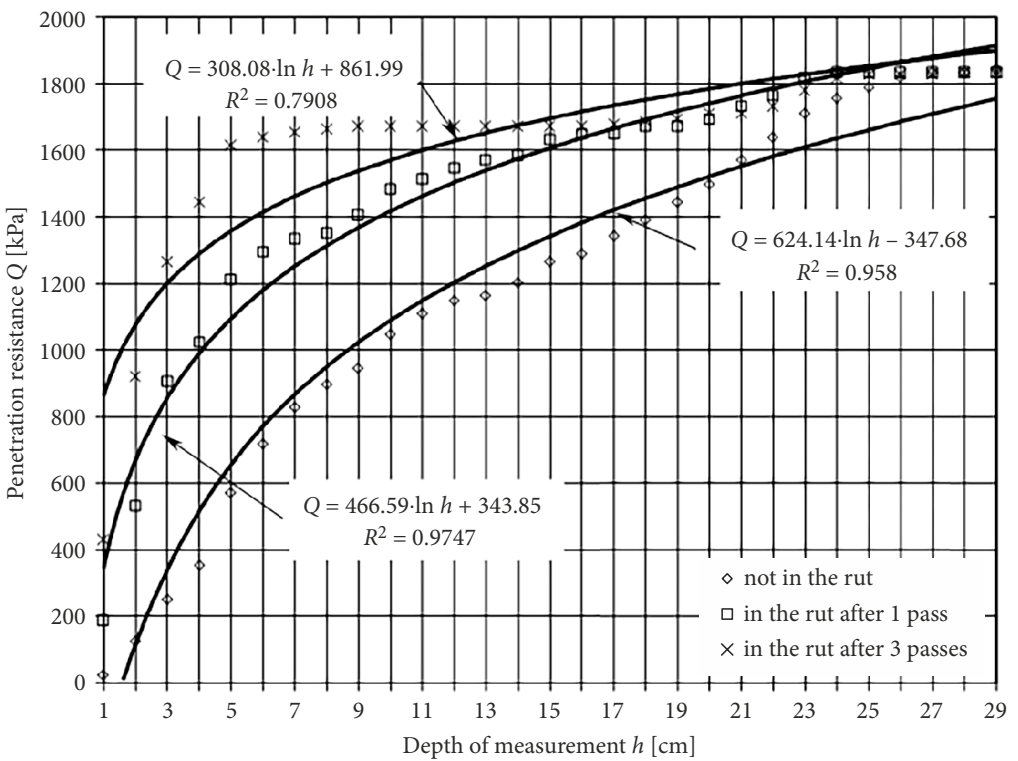

Figure 4 . The relationship between silty clay loam soil penetration resistance and the number of passes of tractor MTZ-82 (average result of all tests is)

tractor MTZ-82, with a tyre pressure of about $0.15 \mathrm{MPa}$; therefore, the maximal pressure of the carriers on the soil reached $0.16 \mathrm{MPa}$. Soil penetration resistance increases with every tractor pass (Figure 4).

The number of drives produces an impact on the soil layer only to a depth of $24 \ldots 26 \mathrm{~cm}$. In deeper layers, the changes of hardness are felt but little (Figure 4). During spring soil preparation, some of the energy input is wasted on overcoming soil resistance and reduction of soil compaction in the autumn tracks. By compaction, soil structure is spoiled and clods form in humid and cloggy soils. Soil compaction increases (in the surface layer in particular) with every new drive in the same tracks (Figure 4). Tractor carriers produce an adverse impact on the density of silty clay loam soil because even after three drives in the same track the soil density approaches the limit value suit for plant growing. Physical degradation of soil sets in, the soil resistance to the working units of aggregates increases as also the energy input for soil cultivation. Environmental pollution with exhaust gases increases as greater amounts of fuel are used for cultivation.

Soil degradation often interacts with terrain and climatic factors defining an ecosystem to reduce sustainable land productivity, which, eventually, threatens food security. Common examples of chemical and physical soil degradation include compaction (due to heavy machinery or repeated tillage operations), systematic loss of aggregate stabilizing soil organic matter, and soil salinization or acidification as a result of problematic drainage, nitrification, or chemical contamination. The greatest soil degradation threat, however, is wind- or water-induced erosion that displaces soil and depresses land productivity, and results in deteriorated physical properties, nutrient losses, and reshaped, potentially unworkable, field surface conditions. Both deterioration and soil erosion are frequently a consequence of using unsuitable management practices because soil resource and climatic constraints are not well understood (Baumhardt et al. 2015).

\section{Conclusions}

On the basis of studies and comparative analysis of machine aggregates for application of manure designed for farms with areas of 28, 90 and 290 ha and annual production of 520, 1665 and $6500 \mathrm{t}$ of manure, the legitimacy of the application of the tested aggregates has been recognized in terms of material and energy inputs, performance data and limited soil compaction. 
Division of manure spreaders into three groups with capacities of 5, 10 and $20 \mathrm{t}$ was justified in terms of the selection of tractors, loaders and acreage of the fertilized fields.

A wide range of commercially available tractors, loaders and manure spreaders requires careful matching of this equipment to the operation of fertilization with manure in terms of soil compaction. Where possible, minimize the number of trips over the field, and reduce the area of your field that is touched by equipment.

The three indicators specifying the degree of soil compaction by the wheels of tractors and manure spreaders proved to be useful in the ongoing study. Each of the indicators determines only a part of the phenomenon of soil compaction in terms of quantity and quality. The indicator defining the percentage of the compacted field surface is particularly important in the case of light machines with small working widths. Indicators related to the field loading by the weight of tractor, spreader and manure as well as the unit loadings in a rut are useful when assessing the aggregates of great loading capacity.

An important indicator is the volume of the ruts created during fertilization. The ruts are undesirable from the point of view of the levelled surface of the field. Creation of ruts consumes much of the tractor engine power (increasing rolling resistance). The volume of ruts formed by the tested manure spreaders, measured under conditions of low soil moisture content, ranged from 61 to $156 \mathrm{~m}^{3} / \mathrm{ha}$.

Improving the technology and organization of work in the fertilization treatment with manure should work towards meeting the requirements of sustainable and organic agriculture, mainly for the reduction of environmental pollution and the destructive impact of tractors, machinery and fertilizer on the soil.

After three drives of tractor MTZ-82 in the same tracks in silty clay loam soils, the penetration resistance increases by $1.10 \ldots 1.65$ times to a depth of $16 \mathrm{~cm}$.

\section{References}

Adamowicz, R. 2003. Zasady rolnictwa zrownowazonego i ekologicznego - proba porownania, Przeglad Techniki Rolniczej $i$ Leśnej (10): 17-19 (in Polish).

Alekseev, V. V.; Maksimov, I. I.; Maksimov, V. I.; Sjakaev, I. V. 2012. Jenergeticheskaja ocenka mehanicheskogo vozdejstvija na pochvu pochvoobrabatyvajushhih mashin i orudij, Agrarnaja Nauka Evro-Severo-Vostoka (3): 70-72 (in Russian).

Álvaro-Fuentes, J.; López, M. V.; Arrúe, J. L.; Cantero-Martínez, C. 2008. Management effects on soil carbon dioxide fluxes under semiarid Mediterranean conditions, Soil Science Society of America Journal 72(1): 194-200. https://doi. org/10.2136/sssaj2006.0310

ASAE S313.3:1999(R2013). Soil Cone Penetrometer. American Society of Agricultural and Biological Engineers Standard.

Baker, A. T. 2014. Soil compaction and agricultural production: a review, in Proceedings of the International Soil Tillage Research Organisation (ISTRO) Nigeria Symposium, 3-6 November 2014, Akure, Nigeria, 182-187.
Baumhardt, R. L.; Stewart, B. A.; Sainju, U. M. 2015. North American soil degradation: processes, practices, and mitigating strategies, Sustainability 7(3): 2936-2960.

https://doi.org/10.3390/su7032936

Berge, H. F. M.; Schröder, J. J.; Olesen, J. E.; Giraldez Cervera, J.-V. 2017. Research for AGRI Committee - Preserving Agricultural Soils in the EU. Policy Department for Structural and Cohesion Policies, European Parliament, Brussels, Belgium. 135 p. Available from Internet: https://www.europarl.europa.eu/RegData/etudes/STUD/2017/601973/IPOL_ STU(2017)601973_EN.pdf

Bernik, R.; Benedičič, J.; Duhovnik, J. 2003. Conceptual design of a stable-manure spreader using a mathematical model, Strojniški Vestnik - Journal of Mechanical Engineering 49(11): 538-548.

BS EN 13080:2002. Agricultural Machinery. Manure Spreaders. Environmental Protection. Requirements and Test Methods. British Standard.

BS EN 690:1994+A1:2009. Agricultural Machinery. Manure Spreaders. Safety. British Standard.

Chen, Y.; Cavers, C.; Tessier, S.; Monero, F.; Lobb, D. 2005. Shortterm tillage effects on soil cone index and plant development in a poorly drained, heavy clay soil, Soil and Tillage Research 82(2): 161-171. https://doi.org/10.1016/j.still.2004.06.006

DeJong-Hughes, J.; Moncrief, J. F.; Voorhees, W. B.; Swan, J. B. 2001. Soil Compaction: Causes, Effects and Control. University of Minnesota, MN, US. 16 p. Available from Internet: https://conservancy.umn.edu/handle/11299/55483

Duhovnik, J.; Benedičič, J.; Bernik, R. 2004. Analysis and design parameters for inclined rotors used for manure dispersal on broadcast spreaders for solid manure, Transactions of the ASAE 47(5): 1389-1404. https://doi.org/10.13031/2013.17604

Duiker, S. W. 2005. Effects of Soil Compaction. College of Agricultural Sciences, Pennsylvania State University, PA, US 12 p. Available from Internet:

https://extension.psu.edu/effects-of-soil-compaction

Hamza, M. A.; Anderson, W. K. 2005. Soil compaction in cropping systems: a review of the nature, causes and possible solutions, Soil and Tillage Research 82(2): 121-145. https://doi.org/10.1016/j.still.2004.08.009

Jabro, J. D.; Iversen, W. M.; Evans, R. G.; Allen, B. L.; Stevens, W. B. 2014. Repeated freeze-thaw cycle effects on soil compaction in a clay loam in Northeastern Montana, Soil Science Society of America Journal 78(3): 737-744. https://doi.org/10.2136/sssaj2013.07.0280

Jabro, J. D.; Iversen, W. M.; Stevens, W. B.; Evans, R. G.; Mikha, M. M.; Allen, B. L. 2015a. Effect of three tillage depths on sugarbeet response and soil penetrability resistance, Agronomy Journal 107(4): 1481-1488.

https://doi.org/10.2134/agronj14.0561

Jabro, J. D.; Stevens, W. B.; Iversen, W. M.; Evans, R. G. 2015 b. Spatial and temporal variability of soil penetration resistance transecting sugarbeet rows and inter-rows in tillage systems, Applied Engineering in Agriculture 31(2): 237-246. https://doi.org/10.13031/aea.31.10722

Kamiński, E. 2011. Trendy rozwojowe w mechanizacji nawożenia mineralnego i organicznego: ekspertyza. Instytut Technologiczno-Przyrodniczy w Falentach Mazowiecki Ośrodek Badawczy w Kłudzienku, Warszawa, Polska. 34 s. (in Polish).

Magdoff, F.; Van Es, H. 2021. Building Soils for Better Crops: Ecological Management for Healthy Soils. SARE Outreach. 410 p. Available from Internet: https://www.sare.org/resources/ building-soils-for-better-crops/ 
McBride, R. A.; McLaughlin, N. B.; Veenhof, D. W. 2000. Performance of wheel and track running gear on liquid manure spreaders, Canadian Agricultural Engineering 42(1): 19-25.

McKenzie, R. H. 2010. Agricultural soil compaction: causes and management, Agri-Facts: Practical Information for Alberta's Agriculture Industry, October 2010, 1-10. Available from Internet: https://www1.agric.gov.ab.ca/\$department/deptdocs. nsf/all/agdex13331/\$file/510-1.pdf

Osman, K. T. 2013. Soils: Principles, Properties and Management. Springer. $298 \mathrm{p}$.

PN-82/R-36108:1982. Ciagniki rolnicze - dolny zaczep transportowy - główne wymiary, wymagania i usytuowanie. Polska Norma. (in Polish).

PN-82/R-36107:1982. Ciagniki rolnicze - zaczep rolniczy - główne wymiary, wymagania i usytuowanie. Polska Norma. (in Polish).

Sainju, U.; O’Brien, D. 2013. Cultural practices to maintain soil quality and address climate change, Agricultural Research Magazine, March 2013, 12-14. Available from Internet: https://digitalcommons.unl.edu/usdaagresmag/65

Taghavifar, H.; Mardani, A. 2014. Effect of velocity, wheel load and multipass on soil compaction, Journal of the Saudi Society of Agricultural Sciences 13(1): 57-66. https://doi.org/10.1016/j.jssas.2013.01.004

Trükmann, K.; Reintam, E.; Kuht, J.; Nugis, E.; Edesi, L. 2008. Effect of soil compaction on growth of narrow-leafed lupine, oilseed rape and spring barley on sandy loam soil, Agronomy Research 6(1): 101-108.

Wyłuda, K. 2007. Doskonalenie technologii nawożenia obornikiem $w$ gospodarstwie farmerskim. Rozprawa doktorska. Instytut Budownictwa, Mechanizacji i Elektryfikacji Rolnictwa, Warszawa, Polska. 105 s. (in Polish).

Żebrowska, E.; Marczuk, T. 2014. Soil compaction with wheels of aggregates for fertilization with liquid manure, Agricultural Engineering 150(2): 229-239. 